\title{
The relationship between \\ an elevated serum amino acid ratio and the development of other biological abnormalities in the experimentally malnourished pig
}

\author{
BY R. F. GRIMBLE* AND R. G. WHITEHEAD* \\ Dunn Nutritional Laboratory, University of Cambridge, \\ and Medical Research Council \\ (Received 7 Fanuary 1969-Accepted 23 April 1969)
}

\begin{abstract}
I. Weanling pigs were fed under three dietary regimens, control, low protein and total calorie restricted.

2. In the protein-deficient group the amino acid ratio did not start to become elevated until growth was impaired and total serum protein and albumin concentration began to fall.

3. In the protein-deficient group, but not in the control or undernourished animals, the magnitude of the ratio was statistically correlated with the rate of growth, appetite, serum protein and albumin concentration and hydroxyproline excretion.

4. The results provide information on the relationship between the serum amino acid ratio and nutritional status.
\end{abstract}

A distortion in the pattern of the serum amino acids is a well-known biochemical characteristic of the type of protein-calorie malnutrition which can terminate in kwashiorkor. The abnormality can be found both in severe cases and in children who show no obvious external signs of malnutrition, although they may have been receiving low-protein diets for many months. The degree of distortion of the serum amino acids can be quantitated by a paper chromatographic method and the results expressed as an amino acid ratio (Whitehead, 1964). The more the amino acid pattern is distorted the higher is the ratio.

Various attempts have been made to interpret the pathological significance of a high amino acid ratio and its relationship to the nutritional status of the child. These investigations have been mainly of two types: one, to measure the ratio on artificially imposed dietary regimens, and these studies have led to the general conclusion that the serum amino acid ratio reflects mainly recent changes in protein intake (Pereira, Begum, Sundararaj \& Dumm, I968); the other, cross-sectional surveys on communities of children have indicated that the amino acid ratio is statistically correlated with other abnormalities associated with malnutrition, including a reduced rate of growth, hair and skin changes and oedema (Whitehead \& Dean, I964a,b).

Neither of these types of investigation is really satisfactory, and the present authors decided that a more valid approach would be to study the progressive effects of primary protein malnutrition on the serum amino acid ratio, and to determine whether a relationship existed between the ratio and any pathological changes developing in other parts of the body. Such investigations in children, however, present

* Present address: MRC Child Nutrition Unit, Mulago Hospital, PO Box 7०5I, Kampala, Uganda. 
considerable problems and it would, of course, be unethical to carry out planned experiments, for prolonged periods, using diets known to be grossly inadequate.

It was natural, therefore, to consider the use of an animal model. An investigation on these lines has already been attempted with dogs by Heard, Kriegsman \& Platt (1968) with interesting results, but their conclusions, in terms of human malnutrition, are questionable. The serum amino acid ratio in their protein-deficient dogs never became elevated and the differences between the normal and malnourished animals were due entirely to a gradual fall in the amino acid ratios of the control animals as they grew older. In children, primary protein malnutrition results in a positive elevation of the amino acid ratio, and an essential feature of any animal experiment designed to study this phenomenon must be that a similar rise in the ratio is reproduced.

The present investigation was planned with the aim of satisfying this requirement and the development of high amino acid ratios has been correlated with various aspects of biological structure and function in the intact animal.

\section{MATERIAL AND METHODS}

\section{Animals}

The thirteen pigs used in this experiment came from two litters of 'Large White' stock, born in consecutive years. From the first of these litters three sows were selected as control animals and were given a high-quality diet throughout the experiment, the remaining three sows and one boar were given a series of low-protein diets. In the second investigation there were two control pigs, one boar and one sow, and two low-protein animals, both boars. A further boar and sow were placed on a calorierestricted diet just to confirm the findings of Whitehead (1967) and Widdowson \& Whitehead (1966) that the serum amino acid pattern was not substantially affected under these dietary conditions, in the pig, as in man and the rat.

The pig was chosen because previous work by McCance \& Widdowson (1966) had suggested it would be a useful animal for this study. In their investigations, however, protein intake was changed abruptly, which immediately resulted in a virtual cessation of growth. Experience in Uganda has shown that no sudden change in rate of growth occurs when children are weaned, and the dietary regimen of this experiment was modified to reproduce a growth pattern more like that found in the chronically malnourished child. This was achieved by gradually reducing the protein content of the diet by varying the proportions of Amvilac No. I (Glaxo Research Ltd, Greenford, Middx), cereal mixture and sucrose. The cereal mixture consisted of 5 parts barley meal, 2 parts maize meal and 2 parts wheatings. The chemical compositions of the various diets used in the experiment are given in Table $\mathrm{I}$.

All animals were weaned at $x 0$ days of age and fed solely on Amvilac for the next 4 days. The control animals were then given $\operatorname{diet} \mathrm{A}, a d$ lib., until they were 8 weeks old, followed by diet $B$ until the end of the experiment. The undernourished group were given the same diets as the control animals but in reduced amounts so that they grew at the same rate as the protein-deficient pigs. The protein-deficient animals were given diets B-H during the periods shown in Table $\mathrm{I}$; they were allowed to feed ad lib. 
Each week every animal was given the vitamin supplement described by Lister \& McCance ( 1967 ), and, in addition, 3250 i.u. vitamin $A$ and 400 i.u. vitamin D, daily, as cod-liver oil. $A$ record was made of the amount of food eaten by each individual animal in the three groups. The low-protein and undernourished animals were weighed each day to facilitate matching of their rates of growth. The control pigs were weighed each week.

Table I. Constituents and composition of the diets given to the experimental pigs

\begin{tabular}{|c|c|c|c|c|c|c|}
\hline \multirow[b]{2}{*}{ Diet } & \multicolumn{3}{|c|}{ Constituents (\%) } & \multicolumn{2}{|c|}{ Composition (\%) } & \multirow{2}{*}{$\begin{array}{c}\text { was given to } \\
\text { low-protein } \\
\text { group } \\
\text { (weeks) }\end{array}$} \\
\hline & $\begin{array}{c}\text { Amvilac } \\
\text { No. } 1\end{array}$ & $\begin{array}{l}\text { Cereal } \\
\text { mixture }\end{array}$ & Sucrose & Protein & $\begin{array}{l}\text { Carbohydrate } \\
\text { (as glucose) }\end{array}$ & \\
\hline A & 70 & 30 & $\circ$ & $25^{\circ} 0$ & $49^{\circ} \mathrm{I}$ & - \\
\hline B & 50 & 50 & $\circ$ & $2 \mathrm{I} \cdot \mathrm{I}$ & 537 & $2-4$ \\
\hline C & 50 & 30 & 20 & $18 \cdot 9$ & 60.7 & $4-6$ \\
\hline $\mathrm{D}$ & 40 & 30 & 30 & $15 \cdot 8$ & $66 \cdot 4$ & $6-8$ \\
\hline $\mathrm{E}$ & 30 & 30 & 40 & $12 \cdot 6$ & $72 \cdot 2$ & $8-10$ \\
\hline $\mathbf{F}$ & 20 & 30 & 50 & $9 \cdot 6$ & $78 \cdot 0$ & $10-12$ \\
\hline $\mathrm{G}$ & 0 & 30 & 70 & $3 \cdot 4$ & 89.5 & $12-13$ \\
\hline $\mathbf{H}$ & 0 & 20 & 80 & $2 \cdot 2$ & $93^{\circ} 0$ & $18-28$ \\
\hline
\end{tabular}

\section{Procedure}

Blood was collected by venepuncture at regular intervals during the experiment from animals who had been fasted overnight. $A$ small sample of this blood was placed in a heparinized container and the remainder was allowed to clot so that serum could be separated. Two consecutive $24 \mathrm{~h}$ samples of urine were obtained at intervals of 2 or 3 weeks from the low-protein and undernourished pigs by placing the animals in a cage adapted for urine collection. Unfortunately, because of the size of the control animals, $24 \mathrm{~h}$ samples of urine could not be collected beyond ro weeks of age when the pigs already weighed $26 \mathrm{~kg}$.

Haematocrit values were determined by centrifugation.

Serum amino acid ratios were measured by the method described by Whitehead (1964). Serum protein and albumin concentrations were estimated by means of an automated system based on 'Technicon' modules. Details of this micro method will be published elsewhere but, essentially, total protein was estimated by the biuret method, and albumin on the basis of its dye-binding capacity with 2-(4'-hydroxyazobenzene)benzoic acid (Ness, Dickerson \& Pastewka, I965). Dye binding varies with different albumins and thus it was necessary to calibrate the analytical system using pig albumin. This was achieved by subjecting some of the samples of pig serum to electrophoresis on cellulose acetate strips as described by Webster (1965). The concentration of albumin was determined by scanning the electrophoretogram with a Chromoscan micro-densitometer (Joyce-Loebl, Gateshead), albumin was then calculated as a percentage of the total protein. A close linear relationship existed between the concentrations of albumin determined by the two methods, thus enabling the colorimetric reaction to be calibrated. Globulin levels were calculated from the difference between the total protein and albumin concentrations. 
Total urinary hydroxyproline was estimated by the method of Prockop \& Udenfriend (1960) and creatinine as described by Bonsnes \& Taussky (I945).

\section{RESULTS}

\section{Food intake}

The mean weight of food eaten per day by the three groups of animals and the energy and protein ingested per kg body-weight are shown in Table 2. In spite of the increasingly poor quality of the low-protein diet, the appetite of the animals receiving it was not significantly smaller than that of the control pigs until week I2. In fact, between weeks 6 and $\mathrm{r} 4$ the kcal intake per $\mathrm{kg}$ body-weight by the protein-deficient group was significantly higher than that of the controls. Moreover, it did not fall below the control level until week 24 although this was partly due to a levelling off in appetite of the control animals with increasing age. The maximum kcal intake per $\mathrm{kg}$ body-weight in the protein-deficient group occurred at week 12 ; it then fell gradually until the end of the experiment.

The protein intake per kg body-weight in the control group rose during the first 8 weeks of the experiment, but this rise did not occur in the protein-deficient group and hence these latter values were significantly below the control levels even at week 8 . The change from diet $\mathrm{F}$ to $\mathrm{G}$ however caused a marked fall in the protein intake per kg body-weight. At week $\mathrm{I}_{4}$ it had dropped to less than ${ }_{15} \%$ of the control level and by the end of the experiment it was as low as $3 \%$.

In the two pigs whose food was restricted, the total calorie intake per $\mathrm{kg}$ bodyweight was always below that of the low-protein and control groups. However, protein intake was greater than in the low-protein group at all times during the experiment, although from week 14 onwards it was much lower than in the controls.

\section{Growth and development}

The rate of weight increase which resulted from these three dietary regimens is shown in Table 3 . Growth in the protein-deficient group only became significantly different from the controls after the animals were Io weeks old, and it was not until week 16 that growth ceased; after week 20 the animals began to lose weight. The dietary design of the experiment had thus achieved the type of growth response which had been hoped for, one which was qualitatively similar to that occurring in the chronically malnourished child. Growth in the undernourished group was essentially the same as in the protein-malnourished pigs.

Of the six animals that had received the low-protein diet, three eventually died and the others were killed when it became obvious they would not survive much longer. One animal died at week 24 and the other two at week 28 . The surviving animals were killed at week 34. At post-mortem all animals exhibited a fatty liver but this was the only consistent pathological finding. Two of the animals that died had a peptic ulcer and one of these exhibited pulmonary oedema; fluid was also present in the pericardial cavity of this animal. The latter abnormality was found in one of the animals that was 


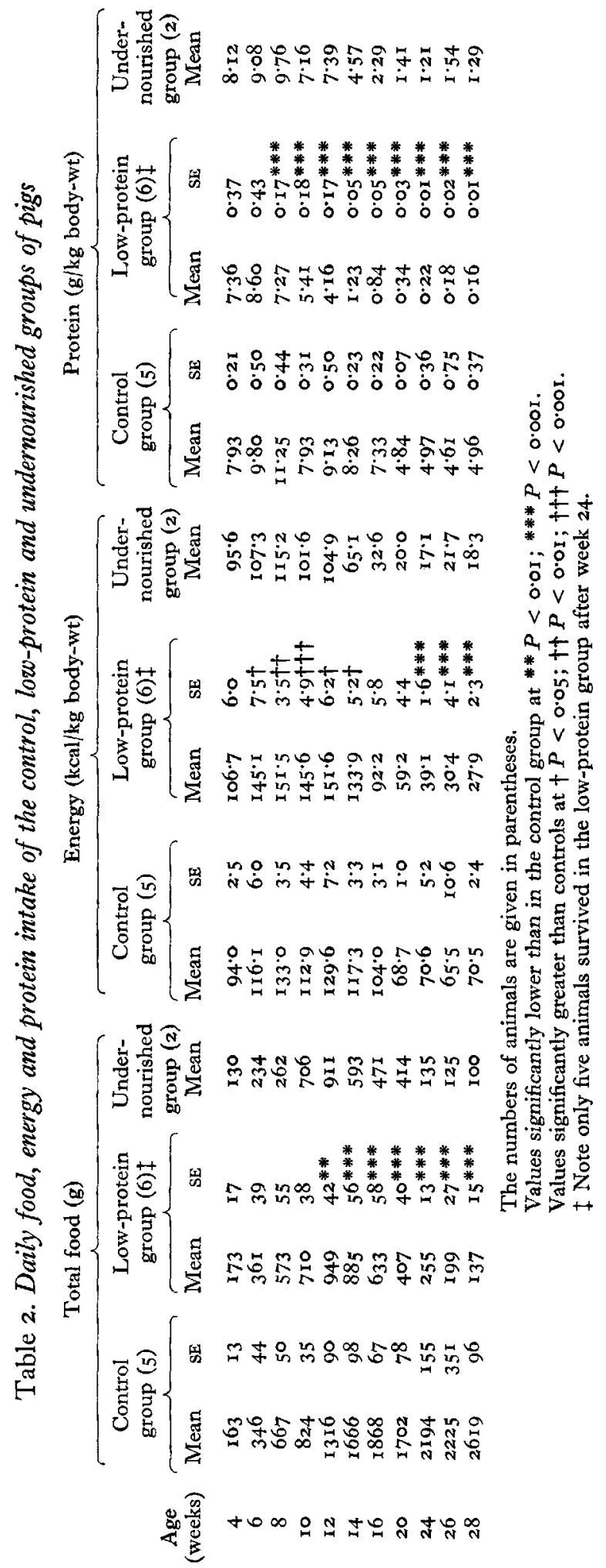


killed, but not in the other two. There was thus no apparent general cause of death other than gross nutritional deficiency.

One major limitation of this experiment must be stressed, however. At no time, even in the concluding stages of the experiment, did any protein-deficient animal remotely resemble a case of kwashiorkor as it is known in children. There was no demonstrable skin oedema, no skin lesions and no hair changes. Gross mental apathy, such a striking characteristic of kwashiorkor, was not apparent. The only obvious behavioural abnormality was severe anorexia.

Table 3. Growth rate (kg/week) of the control, low-protein and undernourished groups of pigs

\begin{tabular}{|c|c|c|c|c|c|}
\hline \multirow[b]{2}{*}{ Age (weeks) } & \multicolumn{2}{|c|}{$\begin{array}{l}\text { Control } \\
\text { group (5) }\end{array}$} & \multicolumn{2}{|c|}{$\begin{array}{c}\text { Low-protein } \\
\text { group }(6) \dagger\end{array}$} & \multirow{2}{*}{$\begin{array}{l}\text { Undernourished } \\
\text { group (2) } \\
\text { Mean }\end{array}$} \\
\hline & Mean & SE & Mean & SE & \\
\hline 4 & 0.98 & 0.08 & 0.81 & 0.13 & 0.50 \\
\hline 6 & $2 \cdot 26$ & 0.19 & $I \cdot 85$ & 0.20 & $I \cdot 30$ \\
\hline 8 & $3 \cdot 48$ & 0.10 & $2 \cdot 66$ & 0.43 & $2 \cdot 20$ \\
\hline IO & $3 \cdot 68$ & 0.45 & $2 \cdot 63$ & $0.19^{*}$ & 3.05 \\
\hline 12 & 3.80 & 0.39 & $2 \cdot 05$ & $0.16 * *$ & $2 \cdot 10$ \\
\hline 14 & $5 \cdot 86$ & 0.46 & 0.60 & $0.25 * * *$ & -0.35 \\
\hline 16 & $4 \cdot 86$ & 0.47 & 0.03 & $0.23 * * *$ & 0.15 \\
\hline 20 & 3.42 & 0.32 & -0.13 & $0.17 * * *$ & -0.70 \\
\hline 24 & $4 \cdot 08$ & 0.67 & -0.35 & $0.09 * * *$ & 0.05 \\
\hline 26 & $4 \cdot 16$ & 0.70 & $-I \cdot I 6$ & $0.54 * * *$ & 0.60 \\
\hline 28 & $5 \cdot 42$ & 0.59 & -0.27 & $0.09 * * *$ & $-0 \cdot 1$ \\
\hline
\end{tabular}

The numbers of animals are given in parentheses.

Growth rate of low-protein group significantly lower than that of controls at * $P<.0 .02, * * P>0.01$, **** $P<0.001$

+ Only five animals survived in low-protein group after week 24 .

The undernourished pigs, who were also killed at week 34, did not have fatty livers, and subcutaneous fat was notably absent. In one, fluid was found in the peritoneal cavity at post-mortem, but the other animal was normal in this respect. The impression was that the undernourished animals could have survived much longer than the lowprotein ones.

In the first experimental litter the protein-deficient animals appeared anaemic and consequently haematocrit measurements were performed in the repeat experiment. There were no marked variations in the haematocrit values of the control group during the experiment and the average was $45 \%$. Low values did develop in the proteindeficient pigs, but the time taken for this to occur was different in the two animals. In one, the haematocrit fell below $40 \%$ at week 8 , but in the other this did not occur until week 22. The haematocrit values continued to fall slowly and by week 28 the values were 21 and $27 \%$ respectively. Such low haematocrit values were not found in the undernourished animals.

\section{Biochemical response}

Changes in the serum amino acid ratios during the experiment are shown in Table 4. The average values in the control animals fell slightly as they grew older although this change was not statistically significant. Heard et al. (I968) found a 
similar fall in the amino acid ratios of normal dogs. The amino acid ratios of the animals receiving the low-protein diets were not different from the controls during the first 10 weeks of the experiment. In the light of experience gained from the first litter, more measurements were made during this initial period in the repeat investigation, which confirmed this finding. After Io weeks, however, the amino acid ratio gradually started to rise and from I4 weeks onwards it was always significantly greater than the control value. This difference between the low-protein and control animals was not just due to the fall in control ratios as it had been in the studies of Heard et al. (1968).

Table 4. Amino acid ratios of the control, low-protein and undernourished groups of pigs

\begin{tabular}{|c|c|c|c|c|c|}
\hline \multirow[b]{2}{*}{ Age (weeks) } & \multicolumn{2}{|c|}{$\begin{array}{l}\text { Control } \\
\text { group (5) }\end{array}$} & \multicolumn{2}{|c|}{$\begin{array}{l}\text { Low-protein } \\
\text { group (6) } \dagger\end{array}$} & \multirow{2}{*}{$\begin{array}{l}\text { Undernourished } \\
\text { group (2) } \\
\text { Mean }\end{array}$} \\
\hline & Mean & SE & Mean & SE & \\
\hline 4 & I. 7 & 0.20 & I. 8 & 0.13 & $I \cdot I$ \\
\hline 10 & $x \cdot 6$ & 0.14 & $1 \cdot 7$ & 0.13 & $I \cdot 4$ \\
\hline 14 & $x-4$ & 0.09 & $2 \cdot 0$ & $0.10 * *$ & $I \cdot 4$ \\
\hline 16 & $I \cdot 4$ & 0.14 & $2 \cdot 3$ & $0.19^{* *}$ & $I \cdot 4$ \\
\hline 20 & $I \cdot 4$ & 0.10 & $2 \cdot 5$ & $0.19 * *$ & $I \cdot 5$ \\
\hline 24. & $1 \cdot 3$ & 0.15 & $2 \cdot 7$ & $0.19 * * *$ & $I \cdot 6$ \\
\hline 26 & $I \cdot 3$ & 0.12 & $3 \cdot 2$ & $0.35 * *$ & I.7 \\
\hline 28 & $\mathrm{I} \cdot 3$ & 0.15 & $2 \cdot 6$ & $0.26 * *$ & I.5 \\
\hline
\end{tabular}

The numbers of animals are given in parentheses.

Control ratio in low-protein group significantly higher than in the controls at $P * 0<0$; *** $P<0.001$.

+ Only five animals survived in low-protein group after week 24.

A definite rise in the amino acid ratio occurred in all six protein-deficient pigs and statistical analysis using the paired $t$ test showed that by week $I_{4}$ the ratios in these animals were statistically higher than the corresponding values at week $4(P<0.05)$, and at week 24 the significance of the rise was even greater $(P<0.01)$. This rise in the amino acid ratio did not, however, continue until the end of the experiment. At week 28 there was a fall in the ratio in four of the five surviving animals. At this stage the animals were very ill and severely anorexic; consequently they were being deprived of both protein and calories.

The amino acid ratios in the undernourished group were as expected from previous studies in man, rat and dog (Whitehead, 1967; Widdowson \& Whitehead, r966; Heard et al. 1968). The ratios did not differ significantly from those found in the control animals, the mean values were all less than $2 \cdot 0$.

The total protein, albumin and globulin concentrations in the sera of the three groups of pigs are shown in Table 5. In the control animals the total protein values rose with increasing age; this is a common finding in most species. Initially, in the lowprotein group there was a similar rise, but only for the first ro weeks of the experiment, and the values during this time were not different from those for the controls. At week I6, however, the serum total protein levels did become significantly lower in the protein-deficient animals. Again, if these differences were to have any meaning in terms of human nutrition it was necessary to demonstrate that they were not merely 


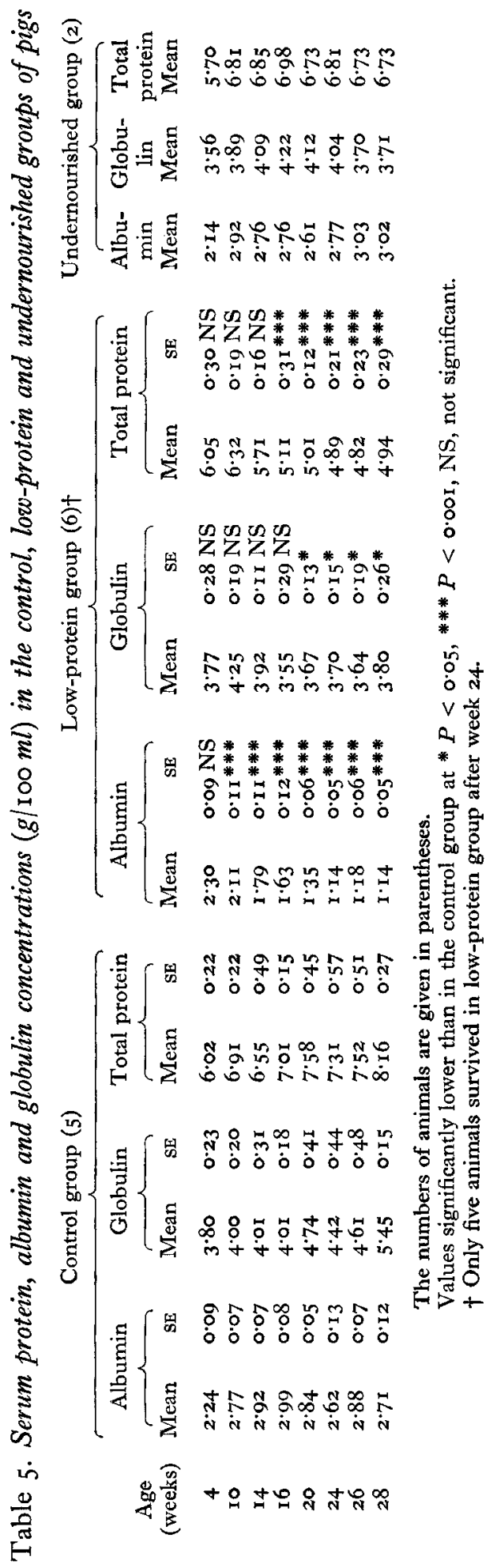


due to a failure of the serum protein concentrations to rise, as they did in the controls, but to an actual fall. The highest serum protein concentration in the low-protein group occurred at week ro and subsequent estimations in each animal were compared with this value by the paired $t$ test. By week 16 there had been a significant fall $(P<0.05)$ and this became more marked at week $20(P<0.0 x)$.

The serum albumin concentrations showed a similar pattern. There was a significant difference between the low-protein and control groups at week ro, due mainly to a failure of the serum albumin levels to rise in the former group, the maximum concentration occurred at week 4 and there was a significant fall below these values at week I4 $(P<0.05)$.

Globulin levels, like total protein, rose in the control animals as they grew older, but in the protein-deficient group this rise only occurred until week 10 , and from then onwards there was no statistically significant change in concentration.

As expected, the developmental pattern of total serum protein, albumin and globulin in the undernourished group was not the same as in the low-protein group. It was, in fact, almost identical with that of the controls, although the total protein and globulin concentrations were somewhat lower after week 16 .

Table 6. Total urinary hydroxyproline and creatinine excretion (m-moles/48 h) in the control, low-protein and undernourished groups of pigs

\begin{tabular}{|c|c|c|c|c|c|c|c|c|c|c|}
\hline \multirow{3}{*}{$\begin{array}{c}\text { Age } \\
\text { (weeks) }\end{array}$} & \multicolumn{4}{|c|}{ Control group (5) } & \multicolumn{4}{|c|}{ Low-protein group (6)† } & \multicolumn{2}{|c|}{$\begin{array}{l}\text { Under- } \\
\text { nourished group (2) }\end{array}$} \\
\hline & \multicolumn{2}{|c|}{ Hydroxyproline } & \multicolumn{2}{|c|}{ Creatinine } & \multicolumn{2}{|c|}{ Hydroxyproline } & \multicolumn{2}{|c|}{ Creatinine } & \multirow{2}{*}{$\begin{array}{l}\text { Hydroxy- } \\
\text { proline } \\
\text { Mean }\end{array}$} & \multirow{2}{*}{$\begin{array}{l}\text { Creati- } \\
\text { nine } \\
\text { Mean }\end{array}$} \\
\hline & Mean & SE & Mean & SE & Mean & SE & Mean & $\mathrm{SE}$ & & \\
\hline 4 & 0.466 & 0.035 & 2.027 & 0.158 & $0.3^{87}$ & 0.048 & $1 \cdot 403$ & 0.143 & 0.340 & I. 5 II \\
\hline 10 & $1 \cdot 522$ & 0.085 & $5 \cdot 205$ & $I \cdot 123$ & $1 \cdot 095$ & $0.187^{*}$ & $5 \cdot 173$ & $1 \cdot 070$ & $I \cdot 586$ & $8 \cdot 098$ \\
\hline 14 & & - & & & $I \cdot 04 I$ & 0.286 & $7 \cdot 114$ & $1 \cdot 139$ & $I \cdot 489$ & $7 \cdot 694$ \\
\hline 16 & & & & & 0.613 & $0.06 \mathrm{I}$ & $7 \cdot 933$ & 0.306 & 0.826 & $11 \cdot 042$ \\
\hline 20 & & & & & 0.296 & $0.06 \mathrm{I}$ & 5.923 & 0.912 & 0.443 & $9 \cdot 550$ \\
\hline 24 & & & & & 0.282 & 0.075 & 5.070 & 0.865 & 0.215 & 9.087 \\
\hline 26 & & & & & 0.244 & 0.067 & 5.705 & $1 \cdot 57^{\circ}$ & 0.136 & $7 \cdot 674$ \\
\hline
\end{tabular}

The numbers of animals are given in parentheses.

* Hydroxyproline excretion possibly significantly lower in the low-protein group than in the controls $(P<0.1)$.

$\dagger$ Only five animals survived in low-protein group after week 24 .

So that previous findings in children could be compared with the present results in pigs, total urinary hydroxyproline and creatinine excretions were also determined; the results are given in Table 6. Comparison with the control animals was only possible up to week ro. Already at this time the excretion of total hydroxyproline per $48 \mathrm{~h}$ was lower in the protein-deficient group $(P=0.1-0.05)$. A marked fall in hydroxyproline excretion occurred at week 16 and it continued to decrease from then onwards. Urinary hydroxyproline levels in the two undernourished animals were similar to those in the low-protein group. Creatinine excretion in the animals given the lowprotein diet was significantly lower than the control values at week $4(P<0.02)$. No explanation for this finding can be given, but by week to the difference had disappeared. Creatinine excretion, contrary to that of hydroxyproline, continued to 
rise in the low-protein group until week $\mathrm{I} 6$ and the values did not fall significantly below this maximum until week 2:4. The average creatinine excretion in the undernourished pigs was higher than that in the low-protein group throughout the period of the experiment.

Table 7. The coefficients of correlation $(\mathrm{r})$ and level of significance $(\mathrm{P})$ for the association between the amino acid ratio of the experimental pigs and other biological measurements from week to onwards

\begin{tabular}{|c|c|c|c|c|c|c|c|c|c|}
\hline & \multicolumn{3}{|c|}{ Control group } & \multicolumn{3}{|c|}{ Low-protein group } & \multicolumn{3}{|c|}{ Undernourished group } \\
\hline & $\begin{array}{l}\text { No. of } \\
\text { samples }\end{array}$ & $r$ & $P$ & $\begin{array}{l}\text { No. of } \\
\text { samples }\end{array}$ & $r$ & $P$ & $\begin{array}{l}\text { No. of } \\
\text { samples }\end{array}$ & $r$ & $P$ \\
\hline Weight gain/week & 40 & -0.04 & NS & 43 & -0.76 & $<0.00 x$ & 19 & -0.11 & NS \\
\hline Total food eaten & 40 & +0.19 & NS & 43 & -0.60 & $<0.001$ & 19 & -0.10 & NS \\
\hline $\begin{array}{l}\text { Dietary protein/kg } \\
\text { body-weight }\end{array}$ & 40 & +0.08 & NS & 43 & -0.64 & $<0.001$ & 19 & -0.02 & NS \\
\hline Total serum protein & 40 & -0.32 & $<0.05$ & 43 & -0.57 & $<0.001$ & 15 & +0.54 & $<0.05$ \\
\hline Serum albumin & 40 & -0.01 & NS & 43 & -0.54 & $<0.001$ & 15 & +0.16 & NS \\
\hline Serum globulin & 40 & -0.45 & $<0.01$ & 43 & -0.38 & $<0.05$ & I5 & +0.47 & $<0.05$ \\
\hline $\begin{array}{l}\text { Urinary } \\
\text { hydroxyproline }\end{array}$ & - & - & - & 27 & $-0.5 I$ & $<0.01$ & 19 & -0.29 & NS \\
\hline Urinary creatinine & - & - & - & 27 & -0.11 & NS & 19 & -0.10 & NS \\
\hline
\end{tabular}

The results indicated that the elevation of the amino acid ratio and the development of most of the other biochemical and biological abnormalities in the low-protein animals all began to appear about the same time, between weeks 10 and 14. Furthermore, after this time, the magnitude of the ratio seemed to be related to the degree of change in these other measurements. To see if this was so, all amino acid ratios in the protein-deficient group from week to onwards were compared with the corresponding values in the other measurements, by means of linear regression analysis, treating each sample as an independent observation. The coefficients of correlation are given in Table 7 . There was a close statistical relationship between the ratio and the weight gain per week, total weight of food eaten, protein eaten per kg body-weight, the serum protein, albumin and globulin concentrations and the hydroxyproline excreted per $48 \mathrm{~h}$. The most striking of these correlations was with the rate of growth. There was, however, no relationship between the ratio and the excretion of creatinine.

In the control and undernourished animals no significant correlations were found, with the exception of those between the ratio and serum total protein and globulin concentrations. The correlation between the amino acid ratio and total protein in the control animals was due to rising globulin levels while the ratio was falling; it was not related to changes in albumin concentration. In the low-protein group, however, the negative correlation between the amino acid ratio and total protein levels was mainly due to the high degree of correlation between it and serum albumin concentration. In the undernourished group there was a positive correlation between the ratio and total protein, but this was mainly because of the effect on globulin levels; there was no significant relationship with serum albumin concentration.

The high correlation coefficients could be the result of large differences between pigs 
rather than being due to the relationships between the factors to which they are attributed, but examination of the results from each individual animal strongly suggested this was not so.

\section{DISCUSSION}

The main dietary feature in this experiment was that the pigs were made gradually protein-deficient. If animals are presented abruptly with a diet containing a small amount of protein appetite is rapidly lost and, since it has been surmised that an adequate carbohydrate intake is necessary before the serum amino acid ratio becomes elevated, such a loss of appetite had to be avoided. With the dietary regimen adopted for this experiment it was possible to reduce the protein concentration in the diet from 25 to $9.6 \%$ before the low-protein animals ate less food than the controls and, in terms of kcal per $\mathrm{kg}$ body-weight, food intake did not fall below the control level until the diet was reduced to $3.4 \%$ protein.

The animals that were given the low-protein diets grew in weight almost as quickly as the controls up to week Io, and it was not until week 14 that their weight started to level off. At week 12 the protein concentration in the diet had been reduced from 9.6 to $3.4 \%$, and protein intake fell from 4.2 to $\mathrm{I} \cdot 2 \mathrm{~g}$ per $\mathrm{kg}$ body-weight. It appeared, therefore, that the period between weeks 10 and $r_{4}$ was a crucial phase in the growth and development of the low-protein animals. It was at week 14 that the amino acid ratios in these animals started to rise, and they continued to do so until near the end of the experiment. Thus changes in the amino acid ratio occurred at the same time as changes in growth. Furthermore, the magnitude of the ratio showed a significant negative correlation with the rate of growth in pigs given a low-protein diet. This finding agrees with the impression gained from cross-sectional studies in children receiving low-protein, high-calorie diets, in whom the ratio was related to weight deficit (Whitehead $\&$ Dean, I964 $b$ ). The negative correlation between the ratio and urinary hydroxyproline excretion also confirms previous work in children (Whitehead, I965; Rutishauser \& Whitehead, 1969) and is further evidence that the elevation of the ratio is in some way related to growth in primary protein deficiency.

Theoretically it could be argued that the alterations in the amino acid pattern resulted from changes in the nature of the dietary protein during the course of the study. Initially the diet consisted mainly of the milk product but eventually the main protein source for the low-protein animals was the cereal mixture. It is well established, however, that the same distortions occur in the fasting pattern of serum amino acids in children with kwashiorkor regardless of the staple protein source (Holt, Snyderman, Norton, Roitman \& Finch, r963), and experiments in rats have shown that elevated amino acid ratios are produced with a variety of foods if the protein concentration is low (Widdowson \& Whitehead, I966; Grimble, Sawyer \& Whitehead, r969).

Heard et al. (1968) concluded from their studies in the dog that serum protein concentration was an earlier index of malnutrition than the amino acid ratio, since, for up to 4 months after their experiment started, serum protein always distinguished the low-protein animals from the controls whilst the amino acid ratio did not do so 
until the 6 th month. This conclusion does not agree with the present findings nor with those from cross-sectional studies in malnourished children by Whitehead \& Dean $(1964 b)$. The latter authors claimed that the amino acid ratio became abnormal sooner than the drop in total serum protein concentration. In this pig experiment the serum proteins started to fall at about the same time as the amino acid ratios rose. Again the experiments with pigs did not reproduce the situation believed to occur in malnourished children, at least in Uganda, and any final conclusion about the relative merits of the amino acid ratio and serum protein measurements in population surveys, on the basis of these experiments, would be unwarranted. The close relationship between the total protein and albumin levels, which are established indices of severe protein malnutrition, and the amino acid ratio in the low-protein animals does support the view that the latter measurement is of pathological importance.

In spite of the difficulties of studying the significance of elevated ratios in man such investigations have been carried out for short periods. Arroyave (1962) fed 'protein free' diets to children, aged 2-5 years for periods up to 15 days; the concentration of branched-chain amino acids had fallen by day 7 . Young \& Scrimshaw (1968) gave similar diets to young adults, and changes in the relative serum concentrations of essential and non-essential amino acids had occurred by day io. Pereira et al. (I968) fed low vegetable protein diets to preschool children and the amino acid ratio rose in 5 days. Swendseid, Tuttle, Figueroa, Mulcare, Clark \& Massey (1966) described a study in which old men received $3.5 \mathrm{~g}$ nitrogen per day. This diet led to a change in plasma amino acid pattern after I week. Other studies in children have confirmed that the amino acid ratio quickly falls into the normal range with successful therapy (Whitehead \& Dean, 1964 $b$; Saunders, Truswell, Barbezat, Wittman \& Hansen, 1967; Pereira et al. 1968). Most of these authors have concluded that because the amino acid ratio responded quickly to changes in the diet it only reflected the quality of the diet and was not a measure of nutritional status.

Further considerations, other than the time taken for a metabolic change to occur, should be taken into account in deciding whether or not a biochemical test has any pathological meaning. In this study the ratio only started to become elevated when the pig was clearly being adversely affected by the quality of the diet. Whitehead (1969) defined a biochemical test for malnutrition as one which had significance in terms of actual or impending changes in essential body structure or function. According to this definition a biochemical change would be a sign of malnutrition if it were associated with other biological abnormalities, resulting from a poor diet. In so far as this animal experiment is concerned the relationships between the ratio and serum albumin and growth provide such information. Growth is very rapid in the pig and consequently it provides a sensitive index of biological function against which biochemical tests can be compared. In the 2-year-old child, however, the rate of weight gain is about roo times less than it is in the young pig and the short-term changes in weight are difficult to detect. Clearly more sophisticated criteria are needed.

Only one published study on human subjects can be related directly to the present investigation. Swendseid et al. (1966) fed three different levels of protein to adult men. A reduction of protein intake from $14 \mathrm{~g}$ nitrogen per day to $7 \mathrm{~g}$ did not affect the 
serum amino acid pattern. The latter protein intake was probably still adequate for health, and most subjects remained in nitrogen balance. Reducing the protein intake further to $3.5 \mathrm{~g}$ nitrogen per day, however, did produce changes in the serum amino acid pattern after to days and by this time all subjects were in marked negative nitrogen balance. In all the other studies quoted, changes in the amino acid pattern were only produced by definitely inadequate diets. Unfortunately, most authors did not provide any additional information about changes in other body measurements, but Young \& Scrimshaw (1968) did find a small but statistically significant fall in serum albumin concentration during the short experimental period. This could be related to the changes in albumin found in the present study.

A discussion about the importance of serum amino acids as a measure of nutritional status should not be confined solely to qualitative changes in pattern; the degree of distortion is equally important. In Uganda, the ratios in severe kwashiorkor are as much as $400-800 \%$ higher than those found in healthy children. In the pig experiment the ratios of the protein-deficient group were eventually only about $200 \%$ above their control values. A possible explanation is that the degree of dietary stress in the pigs was not as great; apart from a fatty liver, the experimental animals never developed clinical signs resembling those found in kwashiorkor. A second reason could be the severe anorexia which developed towards the end of the study; after week 24 the carbohydrate intake of the low-protein animals per kg body-weight was considerably less than that of the controls. The actual fall in the ratio which occurred at week 28 would support this supposition. Whatever the explanation, the failure to reproduce the biochemical abnormality exactly as it is found in children constitutes a shortcoming of this study and consequently only tentative conclusions can be made about the amino acid ratio in terms of malnutrition in childhood. In the experimental studies on human beings the changes were even less marked. Pereira et al. (1968) produced ratios only $50 \%$ above the control levels, and the corresponding changes in the ratios of total essential to non-essential amino acids in the investigations of Swendseid et al. (I966) and Young \& Scrimshaw (I968) were only I00\% and 6r \% respectively. Conclusions based upon such small changes are questionable in terms of primary protein malnutrition in children. If ethics had allowed the experiments to be continued for longer periods, presumably a greater degree of distortion in the serum amino acid pattern would have developed, as it did in the pig. Probably the true significance of the amino acid ratio will only be understood when high values, like those found in children with kwashiorkor, are reproduced under experimental conditions.

On the basis of the present studies and on the evidence gained from various investigations in human beings it is possible to come to some tentative conclusions about the pathological significance of elevated amino acid ratios. It would appear that the ratio does rise fairly quickly when the child or animal is fed on a low-protein, high-calorie diet but only if the diet is so poor that it has some detrimental effect on the body. The fall in the amino acid ratio which accompanies successful treatment might possibly reflect the homoeostatic importance of the pattern of serum amino acids for normal metabolism. Various workers have suggested that changes in the amino acid ratio may be related to the 'labile protein reserve' in the liver. This 
possibility has been investigated in rats (Grimble, Sawyer \& Whitehead, 1969). The resuits from the calorie-restricted animals have again confirmed that the amino acid ratio does not become elevated under these dietary conditions.

It is relevant to end this paper with a word of warning. Controlled nutritional experiments in animals may clarify the relationships between the development of various biological abnormalities, but there is every difference between the simple experimental situation in which only one nutritional variable is introduced and the human situation in developing countries, where protein malnutrition may be only one of many factors affecting the child. These results have confirmed that changes in the amino acid ratio and serum proteins are confined to primary protein malnutrition, but anorexia, bringing with it a total calorie deprivation, can soon complicate this picture. The extreme nutritional disorders typified by the 'sugar baby' and the chronically starved child occupy diminishingly narrow bands on the protein-calorie malnutrition spectrum. A biochemical test, such as the serum amino acid ratio, which is confined to the simple dietary situation where a child is fed on a low-protein, high-carbohydrate diet can have only limited practical value in a more complicated, dietary situation. Nevertheless it is at least of theoretical value to understand more clearly the metabolic and biological significance of an elevated amino acid ratio.

The authors wish to thank Dr E.M. Widdowson for her continued interest, advice and encouragement during this experiment, also $\mathrm{Mr} \mathrm{T}$. Cowan for so patiently feeding the pigs according to our complicated dietary programme. We also acknowledge the post-mortem reports on the animals compiled by $\mathrm{Dr} \mathrm{P}$. Adams and $\mathrm{Mr} \mathrm{P}$. John, and the food analysis supervised by Dr D. A. T. Southgate.

\section{REFERENCES}

Arroyave, G. (1962). Am. $\mathscr{f}$. clin. Nutr. Ir, 447.

Bonsnes, R. W. \& Taussky, H. H. (1945). F. biol. Chem. 158, 581.

Grimble, R. F., Sawyer, M. B. \& Whitehead, R. G. (1969). Br. F. Nutr. 23, 879.

Heard, C. R. C., Kriegsman, S. M. \& Platt, B. S. (1968). Proc. Nutr. Soc. 27, 20 A.

Holt, L. E., Snyderman, S. E., Norton, P. M., Roitman, E. \& Finch, J. (1963). Lancet ii, 1343.

Lister, D. \& McCance, R. A. (1967). Br. F. Nutr. 21, 787.

McCance, R. A. \& Widdowson, E. M. (I966). Lancet ii, 158.

Ness, A. T., Dickerson, H. C. \& Pastewka, J. V. (1965). Clin. chim. Acta 12, 532.

Pereira, S. M., Begum, A., Sundararaj, R. \& Dumm, M. E. (1968). Am. F. clin. Nutr. 21, 67.

Prockop, D. J. \& Udenfriend, S. (1960). Analyt. Biochem. 1, 228.

Rutishauser, I. H. E. \& Whitehead, R. G. (I969). Br. F. Nutr. 23, I.

Saunders, S. J., Truswell, A. S., Barbezat, G. O., Wittman, W. \& Hansen, J. D. L. (1967). Lancet ii, 795.

Swendseid, M. E., Tuttle, S. G., Figueroa, W. S., Mulcare, D., Clark, A. J. \& Massey, F. J. (I 966). F. Nutr. 88, 239 .

Webster, D. (1965). Clin. chim. Acta Ix, Iог.

Whitehead, R. G. (1964). Lancet i, 250.

Whitehead, R. G. (1965). Lancet ii, 567.

Whitehead, R. G. (1967). Archs Dis. Childh. 42, 479.

Whitehead, R. G. (1969). Proc. Nutr. Soc. 28, I.

Whitehead, R. G. \& Dean, R. F. A. (1964a). Am. F. clin. Nutr. 14, 313.

Whitehead, R. G. \& Dean, R. F. A. (1964b). Am. F. clin. Nutr. 14, 320.

Widdowson, E. M. \& Whitehead, R. G. (1966). Nature, Lond. 212, 683.

Young, V. R. \& Scrimshaw, N. S. (I968). Br. F. Nutr. 22, 9. 